The Unfinished History of European Integration 



\section{The Unfinished History of European Integration}

Wim van Meurs, Robin de Bruin, Liesbeth van de Grift, Carla Hoetink, Karin van Leeuwen, Carlos Reijnen 
Originally published as: Europa in alle staten. Zestigjaar geschiedenis van de Europese integratie. Wim van Meurs, Robin de Bruin, Carla Hoetink, Karin van Leeuwen, Carlos Reijnen, Liesbeth van de Grift. Uitgeverij Vantilt, 2013 [ISBN 978946004126 6]

(C) 2013 De auteurs en Uitgeverij Vantilt

Translation: John Eyck (chapters 1 to 4)

Edited by: Amanda Getty and Louise Vines

Cover design: Mijke Wondergem, Baarn

Lay-out: Crius Group, Hulshout

Maps interior: Bert Heesen

Amsterdam University Press English-language titles are distributed in the US and Canada by the University of Chicago Press.

$\begin{array}{ll}\text { ISBN } & 9789462988149 \\ \text { e-ISBN } & 9789048540198 \text { (pdf) } \\ \text { DOI } & 10.5117 / 9789462988149 \\ \text { NUR } & 697\end{array}$

(C) The authors / Amsterdam University Press B.V., Amsterdam 2018

All rights reserved. Without limiting the rights under copyright reserved above, no part of this book may be reproduced, stored in or introduced into a retrieval system, or transmitted, in any form or by any means (electronic, mechanical, photocopying, recording or otherwise) without the written permission of both the copyright owner and the author of the book. 


\section{Contents}

$\begin{array}{ll}\text { Preface } & 7\end{array}$

Introduction 9

1. Many Roads to Europe 21

Theory and Historiography: Federalism and Neofunctionalism 44

The Other Europe: European Officials $\quad 50$

From the Sources: Egodocuments $\quad 57$

2. The European Communities Under Construction 67

Theory and Historiography: Intergovernmentalist Theory 93

The Other Europe: The Court of Justice $\quad 99$

From the Sources: National Archives $\quad 105$

3. What is Europe For? 113

Theory and Historiography: Liberal Intergovernmentalism and the Economic Perspective 139

The Other Europe: European Political Parties $\quad 146$

From the Sources: Opinion Polls 153

4. From Community to Union 163

Theory and Historiography: Multilevel Governance and the $\begin{array}{lr}\text { Rediscovery of the Institutions } & 187\end{array}$

The Other Europe: Think Tanks 196

From the Sources: European Treaties 202

5. A Constitution for a Larger Europe? 209

Theory and Historiography: Constructivism and Democracy $\quad 238$

The Other Europe: The European Central Bank 247

From the Sources: Policy Documents 254

6. From Crisis to Crisis $\quad 263$

$\begin{array}{ll}\text { Widening and the External Crises } & 267\end{array}$

Deepening and the Internal Crises $\quad 272$

An Unfinished History and the Future $\quad 278$ 
Notes

281

About the authors

289

Abbreviations

291

Chronology

295

Bibliography

307

Index

325 


\section{Preface}

No expert on contemporary European affairs can evade the question of whether he or she is 'for' or 'against' the European Union. Yet, if this work has a political purpose, it is to convince its reader that we as citizens share responsibility with national and European politicians for the unique creature the EU has become. Today, probably more so than twenty years ago, Europeans are rethinking and remaking integration, well aware that in one form or another the EU is here to stay. So, this is an 'unfinished' history - the EU is by nature a work-in-progress and we are nowhere near fully understanding its nature.

The present book was initially written for university courses for historians, political and social scientists, and students in cognate disciplines. It avoids jargon unknown to a well-informed newspaper reader and tells its 'unfinished' story in fewer than $15^{\circ}$ pages. All of its contributors lecture on European integration at universities in the Netherlands. The first edition (2013) sought to satisfy the particular demands of two distinct disciplinary worlds: history and political science. Typically, political science textbooks on the EU are precise and systematic in explaining the institutional architecture and theories of integration, but their attention to its history prior to 1979, or even prior to Maastricht, is almost always inadequate. Conversely, even newer historical textbooks often end their narrative with Maastricht and Amsterdam, focussing on leaders and summits to the detriment of institutions and procedures. Our Dutch colleagues have not only encouraged us to take up the gauntlet here, but have also commented on draft chapters and offered answers to intricate EU questions. Meanwhile, five cohorts of students in Amsterdam and Nijmegen, born between the Treaties of Maastricht and Amsterdam, have studied the European Union using this textbook; they in turn gave us plenty of feedback, which has helped us to further improve this edition. We are grateful to Kiran Patel, Ann-Christina Knudsen, Jan-Henrik Meyer and other colleagues at home and abroad, who encouraged us to have this textbook published in English and German for the international reader.

The original edition of this text ended with Croatia's accession to the EU in July 2013. To say that much has happened since is a gross understatement. In this updated version, the introduction has been rewritten to take into account new insights, the five chronological chapters have been updated where necessary, and a sixth chapter on new developments in the EU since 2013 has been added, ending with the first year of formal Brexit negotiations. The chronology and bibliography were updated to 2017 as well. 
The original project for a Dutch textbook on EU history owes much to Marc Beerens of Vantilt Publishers in Nijmegen, who was the first to embrace our aspirations and, together with his editors, helped to turn them into an elegant book. The same goes for the Faculty of Arts at Radboud University in Nijmegen and its History Department. Their financial support helped us to translate the enthusiasm of the initial brainstorm into a fully-fledged book manuscript, for the original Dutch edition and again for the present English edition and the concise German version (published by Dietz Verlag in Bonn, in cooperation with the Bundeszentrale für Politische Bildung). The Pademia Award for outstanding teaching on parliamentary democracy in Europe 2016 additionally motivated us to reconvene for updated editions in English and German. Thanks to the professionalism and commitment of Amsterdam University Press and editor Rixt Runia, the complex process of updating, translating and editing was completed in less than a year, from the publishing contract to the bookstore shelves.

Special thanks go to our assistants Dana van Beurden and Joske Dekkers in Nijmegen for painstakingly compiling the large bibliography and other annexes, as well as for generating the multipurpose index. We are greatly indebted to John Eyck (New York) and Amanda Getty (Los Angeles) who proofread the English manuscript. Needless to say, we are solely responsible for the imperfections that inevitably remain.

Due to its complex institutional and procedural architecture and the political imbroglio of its seven-decade history, the European Union is a challenging subject for a textbook. We hope that we have succeeded in presenting to the reader both less and more than a plethora of historical and contemporary facts and institutional idiosyncrasies: Less, by being highly selective in which events, names and events we chose to include in the text as an introduction to the European Union; and more, by offering context to historical events and a systematic analysis of the institutional architecture. We have succeeded in our mission if the reader finds the seven 'eternal' strategic dilemmas of the integration process, the central theme of this book, useful in making sense of day-to-day media reporting on Europe. We welcome comments and suggestions by students and faculty for an updated edition that will certainly be due in a few years' time, given the pace of European politics today.

Wim van Meurs

Robin de Bruin

Liesbeth van de Grift

Carla Hoetink

Karin van Leeuwen

Carlos Reijnen 


\section{Introduction}

Today, swirling uncertainties as to the mid-term future of the European project constitute a significant challenge to the on-going process of European integration. Predictably, now that the EU is for the first time in its history witnessing a decline in membership, pamphlets proffering sweeping verdicts on Brussels are very much in vogue. The authors of this book, however, believe that recent developments should be met with fresh study into the past and present functioning of the EU and the long-term dynamics of European integration. After all, today's uncertainties and controversies over the future of the European Union not only impact our reading of the present, as is visible in Brexit and the consequent soul-searching of the remaining 27 . Current problems require a revisiting of the historical past. Events like Brexit or the migration crisis motivate historians to review historical crossroads in integration history, which is all too often reduced to unilinear progress. The impact of external structural forces such as climate change or conflict in the Middle East, the autonomous power of grand concepts - federalist aims, monetary union - and the motives of political agents both within and outside the Union are all being re-evaluated and scrutinized anew.

This textbook responds to the demand to revisit the past on two levels. First, in the central chronological chapters, the authors present their versions of a consolidated, uncluttered narrative of European integration. Whereas some of the nuance and alternative perspectives suggested by recent scholarly work may find their way into these chapters, much more of this is offered in the thematic sections that are presented separately. Here, students will find that the challenging of the well-known grand narrative of integration history opens up new vistas for term papers, while the general reader will see how, through new interpretations of past events, political spice is added to present controversies.

As a consequence of today's turmoil, any presentation or interpretation of the history of European integration, no matter how academic or impartial, is inevitably perceived as a public statement weighing in as pro- or anti-Brussels by those championing re-nationalization, a federalist future, a two-speed Europe or an avalanche of national exits. As the reader of older textbooks on European integration will find, the classic narrative of European integration was one of optimism and progress - European integration as an incremental development towards an ever-closer union. In this model, intricacies and tensions, such as the stagnation of the seventies for instance, are reduced to temporary setbacks and decisions made prematurely. The terms 'cul-de-sac,' 
for the aborted plans for a European Defence Community in the fifties, and 'relaunch' for Europe's new ambitions thereafter, testify to this perspective.

Today, the forced optimism of such a historical perspective has gone. By all appearances, this artificially-confident narrative has been replaced by an equally dominant negative one. While the optimistic view transformed any past decision into another step towards European federalism, the pessimistic view anachronizes present controversies, such as the democratic deficit, to the founding decades of the European Communities. In these Eurosceptical accounts just as in the classical narrative, the constraints of historical context are woefully ignored as the (controversies of) today's reality are projected onto the past.

This book is neither an uncritical panegyric nor a vituperative attack on European integration. Instead, the mission of The Unfinished History of European Integration is to unpack the inherent tensions in the concepts and realities of EU history. With the help of the seven 'strategic dilemmas' below, we aim to debunk both the narrative of the inexorable deepening of integration as well as the counter-narrative of 'we the citizens versus Brussels.' The attentive reader will encounter these dilemmas time and again as the chequered life story of Europe unfolds in the chapters that follow. They highlight structural contextual factors, question idealistic motives, identify ambiguities in citizens' expectations and historicize the European project. This exercise neither attempts to proselytize die-hard Eurosceptics nor disconcert staunch believers in an ever closer union. It may, however, provide orientation to all other readers in the arcane and unfinished story of European integration.

\section{Building Europe: Seven Dilemmas}

Throughout the chronological narrative of the European Union, seven 'strategic dilemmas' will help to identify continuity and change in the more than 70 years of its history. The seven dilemmas may be divided into two categories. Four concern conflicts over competencies and responsibilities: Who shapes Europe? The other three relate to the ideals and objectives of the integration process: What should a united Europe be? All seven are permanent issues in the process of European integration. Their relative importance, however, changes over time.

The first dilemma is the one most acutely felt today - citizens versus states. From the very beginning, the EU has represented both member states and European citizens. Tellingly, each member state has its own European 
Commissioner as well as one representative in the European Council or the Council of Ministers. The weight of a minister's vote, however, depends on the size of his or her country's population. Seats in the European Parliament are allocated more or less proportionally to the number of citizens of each member state. Some federalists have gone so far as to suggest that citizens should be able to vote for MPs from any member state. A citizens' initiative requires one million signatures from eight countries. More than any one of the other dilemmas, citizens versus states is inherent to the very process of European integration and is indissoluble.

The next dilemma - intergovernmentalism versus supranationalism - is on the other hand often construed as a binary choice, with the European Union wavering from one extreme to the other. Throughout the decades, both politicians and analysts have used these two terms as a measure to assess any strategic proposal as a choice for 'more' Europe, or 'less.' Realities and ideals have thus evolved around these terms. Fischer's Humboldt speech in 2000 was both hailed and denounced as a supranational endeavour. Half a century earlier, the same qualifications shaped the debate over direct elections for a European Parliament. The transfer of sovereignty to Brussels is real, but observers should be aware that these terms are political weapons as well.

A third dilemma, often eclipsed by the aforementioned tension between Europe as a whole and individual nation states, concerns the division of labour between Europe and the world as a whole. Those who focus on Europeanization tend to forget the parallel process of globalization. Within the expanding Union, the deepening of integration, encompassing ever more policy fields, has led to demands for re-nationalization and a curtailing of European policymaking competencies. In many fields, however, the question is whether Europe has the size and power to cope with key challenges. Environmental issues, terrorism and financial markets respect neither the borders of nation states nor the outer borders of the European Union.

On a slightly different note, the fourth dilemma pertains to the tension between external relations and the domestic affairs of Europe. For most of its existence the European Union has enjoyed a relatively comfortable position in this respect. On the one hand, Brussels has only had EU member states to take into account in setting incremental steps towards enhanced cooperation in (new) policy fields. On the other hand, Brussels has been free to define its own ambitions vis-à-vis neighbouring regions and countries. For a long time, the constellation produced by the Cold War and the Iron Curtain freed Brussels from extensive dealings with neighbours and Union applicants to the east. After the fall of communism, Europe was the only game in town and the single prospective future for more than a dozen countries. All this 
has changed in recent years, with Turkey and Russia offering alternatives to countries in Europe's periphery (and even within the Union) and building their own spheres of influence. Furthermore, both external and domestic tensions have become entangled in critical challenges like Eurosceptical populism, the Syrian and Ukrainian conflicts and, most importantly, the issue of refugees and migrants.

The fifth dilemma of the intertwined dynamics of deepening and enlargement is associated with the fourth. Since the eighties, consecutive rounds of enlargement have tended to coincide with reforms of the European Union. Some have argued that the EU ought to decide on treaty reforms, modified institutional arrangements and major new policies well in advance of the next round of enlargement, as each round taxes political energy and makes consensus harder to come by. Conversely, others have argued that EU member states need the time pressure and the tangible problems that emerge from the accession of yet more nation states to garner the political will needed to overcome deadlock.

Like the fifth, the sixth dilemma concerns the very ideal of Europe. In their strong reliance on technical expertise and the reconciliation of conflicting political and societal interests, the European Communities reveal their origins in the early post-war decades. The High Authority, the European Commission(s), the European Economic and Social Committee and the Court of Justice are cases in point. The rationale of output legitimacy, wherein the European project is validated through the products of its legislative work for all states and citizens, is akin to Monnet's functionalism. In recent decades, the power of the directly elected European Parliament has increased and demands for more citizen participation are louder than ever. Partly due to the EU's sheer size and complex nature as a union of both states and citizens, European politics bear few similarities to the politics of a national polity, the obvious point of reference. Europe's Parliament is not driven by the dynamics of coalition and opposition, and plenary debates fail to enthuse what little European public sphere exists as a consequence. That said, not unlike in national politics today, the public's conflicting demands for the politicization of policy decisions and for de-politicization as an alternative to much-detested politicking, coexist.

The seventh dilemma is a classic, on par with intergovernmentalism versus supranationalism: Is Europe a solid community based on solidarity and shared values or norms? Or is Europe an ephemeral collusion of national interests that is perpetually re-negotiated? Thatcher's 'I want my money back' and the endless debates over the costs and benefits for net contributors to the EU's budget strongly suggest the latter. The recent euro crisis 
and the transfer of billions to Southern Europe have strained the ideal of European solidarity to breaking point. Brexit has arguably demonstrated to most other members the risks and limits of such a utilitarian perception of the EU. If the EU is accepted as legitimate only in its capacity to solve cross-border problems that require collective action, but is mistrusted or even rejected outright for all other policy issues, disintegration may be the result. In non-monetary terms, Turkey, Poland and Hungary have triggered recent debates on inalienable European values with their controversial reforms of constitutional and media laws, much like issues of war guilt and reconciliation in the Balkan countries or the status of non-nationals in the Baltic states.

\section{Understanding Europe: Analytical Challenges}

As these seven dilemmas demonstrate, for those in Brussels and in national capitals attempting to manage European integration, this process is one of avoiding myriad pitfalls and often choosing between two evils. Hindsight is the advantage of historians, who reflect on strategic choices made in the past and their unintended consequences. Those writing the history of this process at the present time, however, find themselves facing challenges of their own. A survey like this book, which aims to contribute to both the history and political science disciplines, to be at the same time innovative and classic, both narrative and systematic, cannot escape hard choices in its set-up and selection of topics.

Perhaps surprisingly, historians are latecomers to the field of EU studies. Prior to the nineties, historical studies on the European Communities in any language of the founding six were few and far between. In the first post-war decades and the early years of European integration, historians were focused predominantly on high politics and national politics; the European treaties and Communities were discussed only on the periphery. Academic disciplines other than history - political science and legal studies in particular - dominate the scholarly literature on the more than half century of EU history. Legal scholars above all are interested in the formal 'reality' of European treaties, institutional architecture and decision-making procedures. Political scientists with a background in international relations view the EU as an intergovernmental organization, whereas their colleagues in comparative politics take the supranational position of Brussels as their point of departure. Interpreting long-term processes and informal interactions beyond the institutional and procedural formalities may provide the 
historian's in. The discipline's attention has recently shifted from the high politics of key figures, conferences and treaties to a more structural and embedded history of European integration as a complex and multi-faceted process, rather than a simple chain of events. Conversely, the multifaceted character of the EU itself and the disciplinary plurality of European Studies, including economists and sociologists as well, are far beyond the competencies of even a large team of authors.

The required conciseness of an introductory textbook thwarts ambitions to present an innovative perspective on the European Union in several respects. No textbook can make do without discussion of quite a number of key actors, conferences, treaties, institutions and other 'memorabilia' from high politics. Societal actors and processes, rather than the eventoriented institutions of low politics, are by default subordinated in such a historical overview. Similarly, the authors are acutely aware of the risk of teleological bias in examining incremental progress from early ideals and ambitions to institutional fruition and membership extension. High politics is particularly prone to omitting alternative options, roads not taken and unfinished projects. Finally, one of the major drawbacks of most EU history writing cannot be remedied here - its de-contextualization. Political events of the Cold War, economic issues such as oil crises or societal trends such as citizens' disenchantment with politics, national and European, cannot be fully and systematically integrated. The systematic and comprehensive bibliography for both generic and thematic studies of European integration since the turn of the century, at the end of this textbook, is intended as a resource for further reading for the student writing a thesis or term paper on the European Union.

\section{An Unfinished History}

Seldom has the direction of European integration been as uncertain as it is now, including as it does the possibility of disintegration. For that reason - and contrary to the customary practice of textbooks and the intuition of historians - the authors have updated this text as late as the publication process would allow. The manuscript was finished in December 2017, in total covering nine decades of European history, from Briand to Brexit.

The authors have opted to first relate the classic historical narrative of European integration in each chapter. Additionally, the first five chapters each include three sections to supplement the historical narrative and the institutions under discussion. The 'Theory and Historiography' section 
introduces paradigms in the development of integration theory in political science, as well as schools of thought in historiography, within the particular temporal context of the chapter, offering further consideration and elaboration of the time period discussed. The 'The Other Europe' section offers selected topics concerning political and institutional actors within the integration process that are often disregarded in the classic narrative of high politics. Finally, the section 'From the Sources' attends to specific categories of sources and introduces basic skills for using them analytically. The latter sections in particular aim at classroom use, providing introductory-level students with practical starting points for their own research projects. More general readers with a primary interest in the historical narrative can easily leave these sections aside. Alternatively, those who have sufficient prior knowledge of institutions and history can study these three sections alone as well - each is varied and comprises approximately 30 pages.

The historical narrative of the European Union is divided into six phases, each with their own central topics that follow both from the experiences of the politicians and citizens for whom European integration is a lived reality, and from the analyses of political scientists, historians and others. As discussed in the first chapter, which ends with the Treaty of Rome (1957-58), the relation of politicians and citizens to the grand ideals of the federalists took centre stage in these initial years, and tensions between normative ideals and political pragmatism is discernable in the work of early EU theoreticians and historians. As Chapter 2 describes, the subsequent era - lasting until the first expansion of the EU in 1973 - witnessed the consolidation of political power relations in the new Europe, the result of struggle between the larger and smaller member states and between member states and European institutions. This highly political and critical phase too had its impact on the development of theory and resulted in a more cynical perspective on the part of historians. In the third phase, from 1973 to 1985 , which is covered by Chapter 3 , both the successes and the conflicts in Europe were more economic than political in nature. Around 1980, the economy was increasingly foregrounded, both in the historical narratives and in the academic search for the driving force behind the integration process.

As Chapter 4 demonstrates, it was not until the leadership of Jacques Delors and Jacques Santer (1985-99) that the political centre once located in the national capitals began to shift to Brussels. The question was no longer whether Europe would increasingly take the lead in policymaking, but how. Historians, political scientists, sociologists and public administration experts likewise began to focus their attention to an increasing extent on the functioning of the EU as a new, unique political system with an 
unprecedented number of policy fields and levels of governance. Consequently, as thematized in Chapters 5 and 6, there is but one question left that interests citizens, politicians and academics alike in the twenty-first century. In many respects, even the euro crisis is derivative of this issue. How do we identify European democracy and its deficiencies? Both in Brussels and in the national capitals the need for a more participatory and representative democracy for the increasingly unpopular European Union is more and more at odds with the need for pragmatic crisis management, including tough measures for saving the euro and coping with the influx of refugees.

Each chapter in this textbook introduces the reader to major theoretical perspectives on European integration in their historical context. After all, theory not only explains the process of integration, but often has a normative function as well, indicating how politics and integration ought to operate. It has influenced the goals and strategies pursued in politics. The development of theory concerning European integration in political science can be described as a succession of schools of thought, which have at their core new questions and lines of inquiry; these questions, as well as their answers, are directly related to the ups and downs of the integration process itself and its perceived character. During the first two decades of European integration, most studies offered explanatory models as to why national governments were willing to transfer sovereignty to an international organization. The integration crisis of the sixties and seventies affirmed the theory of neorealism or intergovernmentalism, which approaches the hybrid EC/EU above all from the perspective of international relations. In the earlier optimistic phase federalists and (neo)functionalists had viewed the (unique) dynamics of European integration with much more confidence, but with the same 'Why?' question in mind.

As states were transferring competences, a new line of inquiry came to light. From the perspective of comparative politics, the how concerning joint European policymaking could now be hashed out, with a focus on Brussels as a new and unique political system. Since the eighties, a third question has also arisen: In whose name has this Europeanization taken place? Alongside the administrative 'How?' the need for democratic legitimacy and public support for policymaking became a matter of increasing concern, both at European and national levels. The discussion of constructivism - e.g. the 'national interest' as a public and political construct, includes democratic and non-democratic forms of influence and the formation of public opinion.

In the historiographical sections, it becomes clear that history writing does not allow for such clear division in schools of thought or for such inflexible coupling of developments in the integration process itself. By virtue 
of the heterogeneity of the discipline and the sources they use, historians are less inclined to choose a theoretical or methodological school explicitly. Additionally, the requirement of a certain temporal distance and the need for lengthy and labour-intensive archival research mean an inevitable delay before there can be any talk of well-defined conceptualizations among historians. However, with a bit of persistence, the pattern in political science texts described above is also recognisable in history texts on the EU. Until well into the seventies, historians showed little interest in the process of European integration. Following the German expert Walter Lipgens, their work focussed above all on Europe as an idea and an ideal, with a clearly normative bias. Just as neo-functionalism emphasises the 'spill-over' effects from optimistic visions of the future, these historians concentrated on the power of the European idea and its advocates. For most historians (just as for the intergovernmentalists among the political scientists), the new communities maintained 'business as usual' - a particular form of multilateral relations between sovereign states. Diplomatic history and archival research was the preview of classic political history in this regard. In view of the fact that most archive legislation provides for access to official documents only after thirty years, it was not until the eighties that studies based on internal negotiation documents could be performed. These tended to emphasize national interests, though attention did shift from international diplomatic history to decision-making and positions taken within each member state. Even as an innovator in archival research, Alan Milward and his famous The European Rescue of the Nation State from 1992 still fits within this realistic school of historiography, in terms of its economic angle and the attention Milward paid to the European Economic Community.

The rise of new approaches to political history in the past twenty or thirty years - from conceptual history to the history of policy fields, from political culture to neo-institutionalism - has also impacted the history of European integration. Just like the development of theory in political science, ideas of a fixed national interest and the state as the (only) arbitrator between its citizens and Europe have grown obsolete as points of departure. In conjunction with the concept of multilevel governance since Maastricht, historians have recently begun to concentrate on European policy development, decision-making and implementation at national level. Similarly, since the nineties the public and political debate has drawn academic attention to the democratic deficit of the European Union. Whereas governance and policy history focus above all on the output of (democratic) policymaking, other historians (together with the constructivists) are interested in forms of representation, advocacy and participation at national and European levels. 
In each chapter that follows, the sections 'The Other Europe' and 'From the Sources' discuss those skills, sources and issues that make innovative contributions to advanced studies concerning the history of integration. New approaches are key to the selected topics, which address historical moments or actors that have remained underexposed from the classic perspective of international relations and the historical narrative sections of this book. As such aspects and actors are numerous, the selected topics (more than elsewhere in the book) bear the signature of the respective authors of the chapters. In 'The Other Europe,' European officials, the European Court of Justice, European political parties, interest groups, lobby organizations and think tanks and finally the European Central Bank are highlighted.

In 'From the Sources,' approaches to different source types are discussed not only on the basis of practical examples but also systematically, including discussions of methodological pointers and pitfalls. Again aiming for the greatest possible variation of the most relevant categories, the sources discussed in these sections vary greatly, from memoirs and other autobiographical documents to national archives, the Eurobarometer surveys, treaties and finally European policy documents. For those who read critically between the lines, these sources yield valuable information concerning underlying conflicts of interest and institutional turf wars.

The reader will explicitly and implicitly encounter the seven strategic dilemmas time and again as the story unfolds in The Unfinished History of European Integration. The analytical challenges are the sole responsibility of the authors. In this respect, the book is a balancing act. It offers a concise narrative of the key actors, events, institutions and treaties in the history and current reality of the European Union. It has been written with the general reader in mind and requires little or no prior knowledge, but offers some additional assistance for secondary school teachers and students in higher education. Finally, students writing a paper or thesis on an EU-related topic may find this book a welcome reference for the historical and institutional basics, a hub for the multidisciplinary and inexhaustible academic literature on the EU, as well as a toolbox of analytical skills.

Wim van Meurs 